\title{
IS THE PERIPHYTIC STRUCTURE OF TESTACEANS (PROTOZOA: RHIZOPODA) RELATED TO WATER QUALITY: A CASE STUDY IN THE CUIABÁ RIVER, BRAZIL
}

\author{
LILIANA ViCTORINO Alves CORRÊA ${ }^{1}$ - EdNA LOPES HARDOIM ${ }^{2}-$ PETER ZEILHOFER $^{3 *}$ \\ ${ }^{1}$ Department of Medicine, Federal University of Mato Grosso, Brazil Av. Fernando Corrêa da \\ Costa $n^{\circ} 2.367$ - Boa Esperança \\ 78060-900 Cuiabá - MT, Brazil \\ (phone: +55-65-3615-8854; fax: +55-65-3615-8854) \\ ${ }^{2}$ Department of Botany and Ecology, Federal University of Mato Grosso, Brazil \\ Av. Fernando Corrêa da Costa $n^{\circ} 2.367$ - Boa Esperança \\ 78060-900 Cuiabá - MT, Brazil \\ (phone: +55-65-3615-8738; fax: +55-65-3615-8738) \\ ${ }^{3}$ Department of Geography, Federal University of Mato Grosso, Brazil \\ Av. Fernando Corrêa da Costa $n^{\circ} 2.367$ - Boa Esperança \\ 78060-900 Cuiabá - MT, Brazil \\ (phone: +55-65-3615-8738; fax: +55-65-3615-8738) \\ *Corresponding author \\ e-mail: zeilhoferpeter@gmail.com \\ (Received $5^{\text {th }}$ Nov 2013; accepted $14^{\text {th }}$ Aug 2014)
}

\begin{abstract}
Presented study describes the periphytic community of Testaceans of the Cuiabá River, Central Brazil and evaluates its relationships to physical, chemical and biological water characteristics. Three sampling stations were established along an urban reach passing Cuiabá city, realizing four campaigns at the right and left river margins. Canonical Correspondence Analysis was conducted to study relationships of chemical and physical water characteristics with the colonization of the periphytic community of Testaceans on artificial substrata. Assemblage composition varies according to seasonal hydrological cycles and water quality, as well as spatially along the pollution gradient reflected by sampling sites along the river reach. Species richness and abundance showed highest values during the dry season, being Cochlyopodium, Centropyxis and Cyclopyxis the most common genera. The genus Centropyxis was frequent at all sampling stations throughout the year, being dominant at the highest impacted station. 27 of the 28 Difflugia species were only observed in the dry season under low flow velocities and discharge and have little potential as indicator of water quality parameters. On the other hand, species such as Cyclopyxis plana microstoma and Euglypha acanthophora only occured at impacted sampling stations, independently of the season, indicating a potential for bioindication.
\end{abstract}

Keywords: testate amoeba, periphyton, artificial substrata, Central Brazil

\section{Introduction}

Between the diverse groups of water quality indicators, periphyton communities have been widely applied for the study of pollution estate in lotic ecosystems. According to Ward (1989), lotic environments have primary heterotrophic functions and reflect therefore the characteristics of its contributing watersheds (Lampert and Sommer, 1997). Therefore, basins geoecology and land use reflect on spatial distribution and colonization processes of protozoaria communities. Most studies focused on the ecology on algae assemblages in freshwater ecosystems (Barinova et al., 2006; Gaiser et al., 2006; Carr et al., 2005; Vis et al., 1998). The group of sarcodian protozoae (Testacea), 
however, is supposed to have advantages for ecological approaches: they are abundant in many aquatic ecosystems, produce high amounts of biomass and its size and reproduction cycles allow investigations about demographic processes. As they are cosmopolitans, the regional auto-ecology of species can be compared with that of other regions.

Quantification of testate amoeba on natural substrata implicates in a series of methodological problems, particularly if quantitative results should be obtained. Therefore artificial substrates have been suggested for sampling (Cooke, 1956; Sládecková, 1962; Cairns et al., 1979; Schwarzbold, 1990). The studies of Castenholz (1961), Sladecek and Sládecková (1993) and Strüder-Kypke (1999) identified glass slides to be appropriate as artificial substrates to study periphyton fauna. Different incubation periods for glass slides had been proposed for the study of periphyton communities (Brown and Austin, 1971). For approaches, which use direct observation of species by microcopy, incubation periods of glass should not exceed one month. Godinho-Orlandi and Barbieri (1983) stated highest number of individuals of protozoa population after 21 days of colonization, after testing periods of 2, 3, 7, 14, 21 and 28 days.

Despite the significant amount of ecological studies on the testate amoebae communities in rivers of temperate climates (Jax, 1996; Opravilová, 1986), little is known about their distribution and its suitability as ecological indicators in sub-humid tropical, lotic ecosystems. The few available studies for South American freshwater ecosystems refer to plankton communities (Lansac-Tôha, 2000, Velho et al., 1999, Walker, 1982). Until the mid 70ties, studies on periphyton communities in the Central Western regions of Brazil were restricted to general, descriptive biogeographical approaches (Cunha, 1916, Green, 1975). Even the more recent studies carried out in Brazil (Lahr and Lopes, 2006; Lansac-Tôha et al., 2007, 2008) and the Mato Grosso state (Hardoim and Heckman, 1996, Lansac-Tôha et al., 2001, Hardoim, 1997, Silva Neto, 2001, Missawa, 2000) give only a very limited image of spatio-temporal distribution of Testacea fauna and its ecological determinants.

Many Testacea were supposed to be poor indicators for water quality, as they can tolerate a broad spectrum of environmental factors (Green, 1975; Ogden and Hedley, 1980; Opravilová, 1986). The Testacea are mostly anchored to the substrate with only a temporary adhesion by pseudopods, leading to a weak competitive ability and passive relocation and are therefore often restricted, in higher species diversity and density in competition poor habitats. At least in lentic environments, Testacea however have been related successfully to water quality (Patterson and Kumar, 2002; Kumar and Patterson, 2000). Roe et al. (2010) showed a strong association of thecamoebian assemblages with the trophic status of lake sediments. Escobar et al. (2008) related the structures of assemblages to $\mathrm{pH}$ in subtropical Florida lakes to organic matter content and $\mathrm{pH}$ and pointed out that diversity indices are higher in mesotrophic to eutrophic lakes than under dystrophic conditions.

In this context in present study we investigate, if Testacea periphyton communities have a potential as indicators to evaluate the pollution gradient along a urban reach of the Cuiaba river, which passes the most densely populated region of Mato Grosso state, Central Brazil. More specifically, we analyze the influence of pollution gradients and the climatic driven temporal variations of water quality on the assemblage composition. 


\section{Study Area}

The upper Cuiabá River is one of the main tributaries of the northern Pantanal, the world greatest floodplain. Its watershed covers, river ahead the Pantanal, about 28.700 $\mathrm{km}^{2}$ and is located between $14^{\circ} 18^{\prime}$ and $17^{\circ} 00$ s.L. and $54^{\circ} 40^{\prime}$ and $56^{\circ} 55^{\prime}$ w.L in the southern part of the Mato Grosso state (Fig. 1).

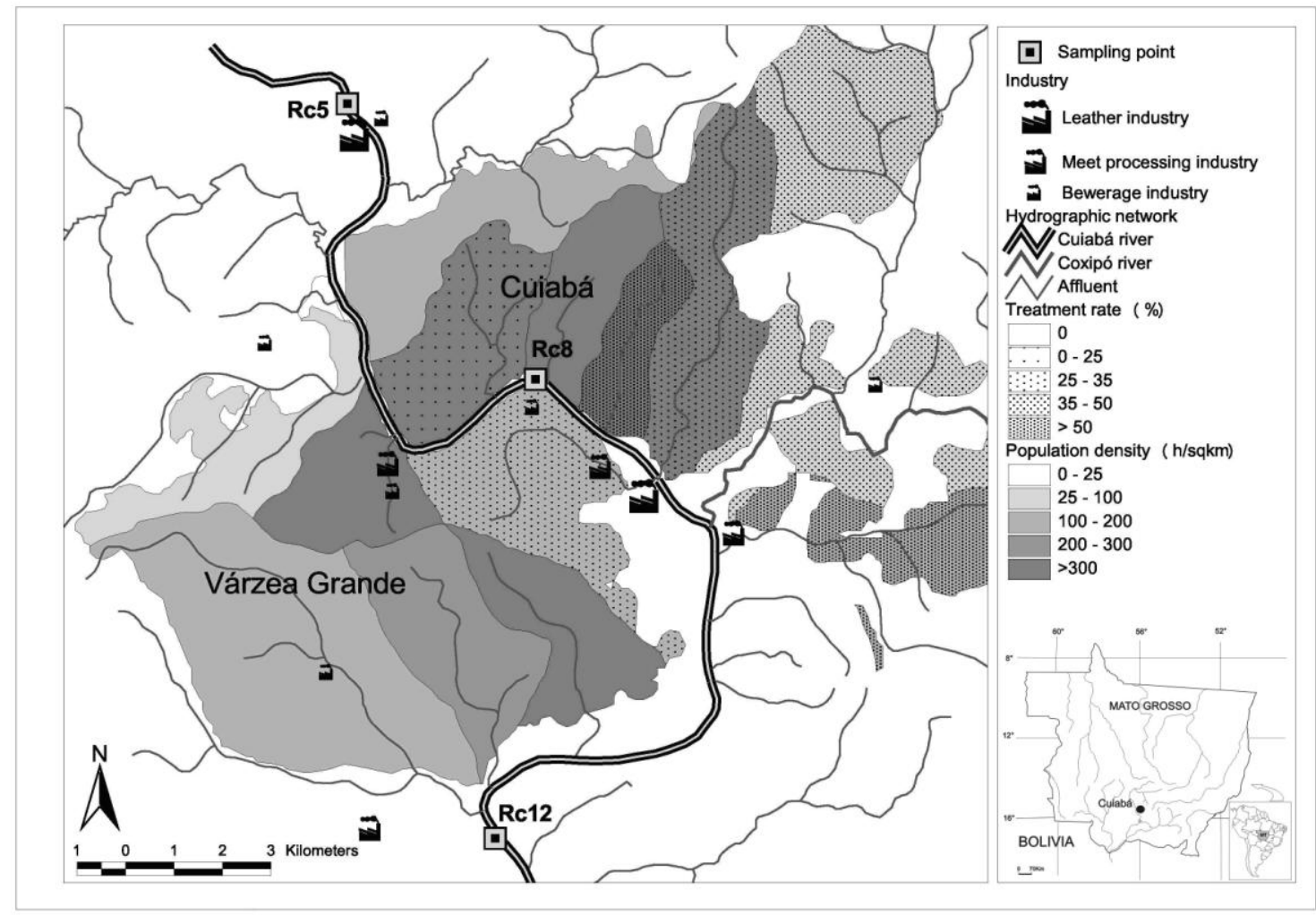

Figure 1. Sampling stations in the urban agglomeration of Cuiabá and Várzea Grande. Subwatersheds are colored according to population density and wastewater treatment taxes.

The tropical sub-humid climate in the basin is characterized by mean annual temperatures between 22 and 25 degrees and a mean precipitation of $1342 \mathrm{~mm}$ (19601998) in the urban agglomeration of Cuiabá and Várzea Grande with maxima of up to $2000 \mathrm{~mm}$ in the headwater regions of the Cuiabá river. Precipitation and river runoff present an expressive seasonality. More than $80 \%$ of rainfalls are concentrated in the months of November through April. The average monthly stream discharge at a gauging station in Cuiabá City varies between about $800 \mathrm{~m}^{3} / \mathrm{s}$ in April and $100 \mathrm{~m}^{3} / \mathrm{s}$ in September (1984-1999). The lower parts of the watershed are formed by Pre-Cambrian metasediments of the Cuiabá group, the Manso and Casca river headwaters are located in the mountain ranges of the Planalto of Guimarães, mainly formed by sandstones. The upper Cuiabá River crosses calcareous formations of the Pre-cambrian Alto Paraguai group. Cerrado savannahs, the main vegetation formation of the watershed are mainly occupied by extensive cattle farming, in the plateaus of the mountain ranges native vegetation had been widely substituted for the cultivation of soybeans and cotton.

In 2002, the urban agglomeration of Cuiabá and Várzea Grande city had a population of more than 720,000 inhabitants. It is estimated, that less than $30 \%$ of domestic 
effluents are treated and that about $95 \%$ of organic loads in the watershed are introduced in the Cuiabá River in the urban agglomeration (Zeilhofer et al., 2010). Nonpublished, population-based estimates for the year of 2006 indicate that more than $30 \mathrm{t}$ of organic loads are daily introduced along river reaches in the urban agglomeration of Cuiabá.

\section{Methods}

\section{Sampling}

Artificial substrata were installed at three monitoring stations, each composed by two sampling points at both river margins, representing a pollution gradient along a 28 kilometers urban reach of the Cuiabá river (Fig. 1). First station (Rc5) is located river ahead of the urban perimeter, receiving only diffuse pollution loads from extensive agricultural activities and some aquacultures. The sampling point Rc8 is located about $300 \mathrm{~m}$ above the Gambá stream in the central area of the urban agglomeration. Rc12 is a sampling point river downstream the Cuiabá/Várzea Grande agglomeration, after the Cuiabá river receiving principal organic contributions from the urban watersheds. Chemical, physical and biological water quality samples were collected during the campaigns for installation and removal of the artificial substrata, at both river sides (sampling points of Testacean colonization) and for the main channel. Four sampling campaigns were conducted, two during the dry season (15/08/2000 and 30/08/2000) and two during the rainy season (08/03/2001 and 09/04/2001). Water quality analyses were conducted according to APHA - Standard Methods (Tab. 1).

Table 1. Methods applied for physical, chemical and biological parameters of water quality monitoring.

\begin{tabular}{|c|c|c|c|}
\hline Parameter & Acronym & Analytical technique & Unit \\
\hline Alkalinity & Alka & Titrometry & $\mathrm{mg} \mathrm{CaCo} / 1$ \\
\hline Biological Oxygen Demand & BOD5 & 5-Day BOD test & $\mathrm{mg} \mathrm{O}_{2} / 1$ \\
\hline Chemical Oxygen Demand & COD & Closed reflux, colorimetric & $\mathrm{mg} \mathrm{O}_{2} / 1$ \\
\hline Fecal coliforms & $\mathrm{FC}$ & Multiple-tube fermentation & MPN/100ml \\
\hline Total coliforms & $\mathrm{TC}$ & Multiple-tube fermentation & MPN/100ml \\
\hline Color & Color & Visual comparison & Chloroplatinite \\
\hline Condutivity & Cond & Conductometry & $\mu \mathrm{S} / \mathrm{cm}$ \\
\hline Dissolved Oxygen & DO & Potentiometry/O2 probe & $\mathrm{mg} \mathrm{O}_{2} / 1$ \\
\hline Total Kjedahl Nitrogen & TKN & $\begin{array}{l}\text { Block digestion, } \\
\text { spectrophotometry }\end{array}$ & $\mathrm{mg} \mathrm{N} / \mathrm{l}$ \\
\hline $\mathrm{pH}$ & $\mathrm{pH}$ & Electrometric method & $\mathrm{pH}$ units \\
\hline Total phosphorous & TP & Ascorbic acid & $\mathrm{mg} \mathrm{P} / \mathrm{l}$ \\
\hline Total solids & TS & Drying at $100^{\circ} \mathrm{C} /$ weighting & $\mathrm{mg} / \mathrm{l}$ \\
\hline Temperature & Temp & Temperature probe & ${ }^{\circ} \mathrm{C}$ \\
\hline Turbidity & Turb & Nephelometric method & NTU \\
\hline
\end{tabular}

Testacean communities were sampled using artificial substrates with replicas, composed by two previously sterilized glass slides. At each sampling point a total of six pairs of glass slides were disposed in a metallic grid. Fixed at the bottom of the water course at a distance of about 1 meter from the river border, the sampling modules were disposed parallel to the stream current in order to reduce selective effects (Kralik 1957/58). After 16 days, glass slide replicas were removed, fixed in a $4 \%$ formol solution and colored 
with an indicator of viability Bengal's Rose. Identification of testate amoeba was done by optical microscopy. Replicas were considered as a unique sampling unit, summing species counts of glass slides. During the wet season, inferior parts of glass slides were in some cases covered by sediments. Testate counts were therefore extrapolated proportionally to the non-populated glass slide area. Sampled material is available for consultation at the Laboratory of Taxonomy and Ecology of Aquatic Microorganisms LATEMA, at the Bioscience Institute of the Federal University of Mato Grosso.

\section{Data Analysis}

\section{Direct gradient analysis}

Canonical Correspondence Analysis (CCA) was conducted to evaluate relationships between water quality variables and community structure of Testacea protozoa. CCA is a direct gradient analysis (ter Braak and Prentice, 1988), where a matrix Y of dependent variables (species) is ordinated under the constraint of a matrix $\mathrm{X}$ of explanatory variables or predictors (water quality data). CCA is indicated for ordination, if dependant variables have a unimodal distribution along environmental gradients. In their comparison of CCA with General Linear Models (GLM), Guisan et al. (1999) pointed out that CCA has good performance in ordination of multiple species. General null hypothesis of CCA, that there is no relationship between the response and explanatory variables (independence of $\mathrm{Y}$ and $\mathrm{X}$ ), or that the model is not significant, can be tested through a permutation test, where a pseudo-F statistic of the unpermuted data is repeatedly compared with the pseudo-F statistic of permuted data (Anderson and ter Braak, 2003). As CCA is supposed to be biased by rare species (Legendre and Gallagher, 2001), only species with relative frequencies above $20 \%$ were considered in ordination. Both dependent variables (species abundance) as well as explanatory variables were log-transformed for ordination. CCA was conducted with the RDACCA software (Makarenkov and Legendre, 2002). Significance of ordination axis was tested applying a Monte Carlo randomization test with 5000 permutations.

\section{Results}

A Mann-Whitney test for paired samples of the three sampling stations along the urban reach of the Cuiabá river showed significant differences $(p<0.05)$ between dry and wet season for most water quality variables. Only TC and FC counts do not differ statistically due to strong dilution effects in the streams during the rainy season (Tab. 2).

Table 2. Physical, chemical and biological water quality variables for the three sampling stations at each sampling point (main channel, left and right margin) and for the two sampling dates.

\begin{tabular}{|c|c|c|c|c|c|c|c|c|c|c|c|c|c|}
\hline & & $\mathrm{H}$ & $\begin{array}{c}\text { Color } \\
u H\end{array}$ & $\begin{array}{c}\text { DO } \\
\text { mg/l }\end{array}$ & $\begin{array}{c}\text { COD } \\
\mathrm{mg} / \mathrm{l}\end{array}$ & $\begin{array}{c}\text { BOD5 } \\
\text { mg/ }\end{array}$ & $\begin{array}{l}\text { Alcal } \\
\mathrm{mg} / \mathrm{l}\end{array}$ & $\begin{array}{l}\text { Turb } \\
\text { UNT }\end{array}$ & $\begin{array}{l}\mathrm{SST} \\
\mathrm{mg} / \mathrm{l}\end{array}$ & $\begin{array}{c}\text { TP } \\
\text { mg/ }\end{array}$ & $\begin{array}{c}\text { TN } \\
\text { mg/1 }\end{array}$ & $\begin{array}{c}\text { TC } \\
\text { NMP } / 100 \mathrm{ml}\end{array}$ & $\begin{array}{c}\text { FC } \\
\mathrm{NMP} / 100 \mathrm{ml}\end{array}$ \\
\hline \multirow{3}{*}{$\begin{array}{l}\text { Dry } \\
\text { season }\end{array}$} & & & 20.00 & 7.12 & 7.80 & 1.04 & 37.05 & 4.94 & 9.33 & 0.04 & 0.19 & 234 & 234 \\
\hline & 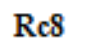 & .98 & 5.11 & 6.83 & 4.05 & 0.98 & 36.78 & 5.62 & 17.00 & 0.06 & 0.39 & (3) & 33019 \\
\hline & Rcl2 & 7.84 & 32.22 & 6.46 & 8.68 & 1.33 & 34.72 & 7.54 & 21.78 & 0.09 & 0.45 & 43260 & 43260 \\
\hline \multirow{3}{*}{$\begin{array}{l}\text { Wet } \\
\text { season }\end{array}$} & Re5 & .59 & 72.08 & 4.62 & 11.82 & 1.83 & 10.52 & 46.67 & 42.83 & 0.16 & 0.37 & 586 & 66 \\
\hline & Re8 & 7.52 & 60.83 & 4.66 & 21.44 & 1.80 & 10.66 & 40.83 & 41.06 & 0.12 & 0.59 & 7076 & 5749 \\
\hline & Rcl2 & 7.41 & 77.92 & 4.63 & 21.25 & 1.51 & 9.91 & 46.08 & 43.42 & 0.15 & 0.79 & 19950 & 17443 \\
\hline
\end{tabular}


PH, DO and Alkalinity were higher during the dry season, when Color, COD, BOD, Turbidity, SST, TP and TN concentrations were higher during the wet season.

These results appoint for a cyclical deterioration of physical and chemical water quality during the months November through April (rainy season) due to the local geographic specifities. During this period first flush events drain dry deposition components to the streams. In addition, water treatment plants in the urban agglomeration of Cuiaba and Varzea Grande city have frequently an overloaded capacity during and after rain storms, causing massive inflow of untreated wastewater in the Cuiaba river (Zeilhofer et al., 2010).

A comparison between the stations Rc5 and Rc8 (Wilcoxon paired sample test) resulted in significant differences for the variables $\mathrm{pH}$, Turbidity, CT and TC. Water quality alterations turn more expressive when the stations Rc5 and Rc12 are compared. Values obtained for $\mathrm{pH}$, color, DO, COD, Alkalinity, TC and FC differ significantly $(\mathrm{p}<0.05)$. Tributaries of urban watersheds mainly reflect on indicators of organic pollution such as decreasing DO and increase of COD and coliform counts. TN concentrations show significant increase between the stations Rc5 and Rc12 for the samples of both seasons; TP concentrations significantly increase between Rc5 and Rc12 during the wet season.

Table 3 presents seasonal species densities, which are averages from the two samplings points (left and right river margin) at each river station (Rc5, Rc8, Rc12), as well as species abundance and richness. Total abundance was highest at station Rc8 at both seasons and species. Richness was higher at this station than at the little impacted station Rc5 and similar as at station Rc12. During sampling campaigns of both seasonal periods Cochlyopodium, Centropyxis and Cyclopyxis were the most common genus. The genus Cochlyopodium, represented only by one species (Cochlyopodium vestitum) was abundant at each sampling campaign. Specimen counts, however, were lower during the wet season. The genus Centropyxis (8 species) was frequent at all sampling stations throughout the year, being dominant at highly impacted station Rc12 during the dry season. The three species of the Cyclopyxis genus were more common at the impacted stations Rc8 and Rc12, during both seasons. The genus Difflugia is represented by 28 species, but none of them was abundant inside the assemblages. Specimen counts were generally much higher during the dry season. With exception of Euglypha acanthophora, species of the genus Euglypha (three species), Pseudodifflugia and Pyxidicula (one species each) are rare during both seasons.

Table 3. Individuals at sampling points, averaged for left and right river margins.

\begin{tabular}{|c|c|c|c|c|c|c|}
\hline \multirow[b]{2}{*}{ Sampling station } & \multicolumn{3}{|c|}{ Dry season } & \multicolumn{3}{|c|}{ Wet season } \\
\hline & Rc5 & Rc8 & Rc12 & Rc5 & Rc8 & Rc12 \\
\hline Arcella dentata (Ehrenberg, 1838) & 0 & 2 & 0 & 0 & 0 & 0 \\
\hline Arcella discoides (Ehrenberg, 1843) & 11 & 94 & 90 & 1 & 1 & 45 \\
\hline Arcella hemisphaerica (Perty, 1852) & 1 & 6 & 0 & 5 & 0 & 8 \\
\hline Arcella lobostoma (Deflandre) & 0 & 0 & 0 & 4 & 0 & 0 \\
\hline Arcella vulgaris (Ehrenberg, 1830) & 0 & 8 & 2 & 0 & 0 & 0 \\
\hline Centropyxis aculeata (Ehrenberg, 1830) & 36 & 157 & 218 & 25 & 41 & 125 \\
\hline Centropyxis sp. & 0 & 0 & 0 & 1 & 96 & 0 \\
\hline Centropyxis cassis (Wallich, 1864) & 1 & 0 & 0 & 0 & 0 & 0 \\
\hline Centropyxis constricta (Ehrenberg, 1841) & 1 & 1 & 2 & 0 & 0 & 0 \\
\hline Centropyxis discoides (Pénard, 1890) & 3 & 10 & 19 & 0 & 12 & 12 \\
\hline Centropyxis ecornis (Ehrenberg, 1841) & 19 & 82 & 268 & 10 & 122 & 20 \\
\hline Centropyxis platystoma (Pénard, 1890) & 0 & 0 & 1 & 0 & 0 & 0 \\
\hline
\end{tabular}


Centropyxys hirsuta (Deflandre, 1929)

Cochlipodium vestitum (Archer)

Cyclopyxis arcelloides (Penard, 1902)

Cyclopyxis eurystoma (Deflandre, 1929)

Cyclopyxis plana microstoma (Schönborn,1966)

Difflugia acuminata (Ehrenberg, 1838)

Difflugia ampulla (Ehrenberg, 1840)

Difflugia bicruris (Gauthier-Lievre and Thomas,

Difflugia brevicolla (Cash, 1909)

Difflugia bryophila (Penard)

Difflugia distenda (Ogden)

Diffludia elegans (Pénard, 1890)

Difflugia gassowskii (Ogden)

Difflugia glans,(Pénard, 1902)

Difflugia globularis (Wallich, 1864)

Difflugia gramen,(Pénard, 1902)

Difflugia lobostoma (Leidy, 1879)

Difflugia lucida (Pénard, 1890)

Difflugia manicata (Pénard, 1902)

Difflugia mamillaris (Pénard)

Difflugia mica (Frenzel, 1897)

Difflugia minuta (Rampi, 1950)

Difflugia mitriformis (Wallich)

Difflugia molesta (Pénard, 1902)

Difflugia oblonga (Ehrenberg, 1838)

Difflugia penardi (Cash)

Difflugia petricola (Cash, 1909)

Difflugia pristis (Penard, 1902)

Difflugia pyriformis (Perty, 1885)

Difflugia rubescens (Penard, 1891)

Difflugia tenuis (Penard, 1890)

Difflugia urceolata (Carter, 1864)

Difflugia venusta (Ogden, 1983)

Euglypha acanthophora (Ehrenberg, 1841)

Euglypha capciosa (Couteaux, 1978)

Euglypha laevis (Ehrenberg)

Euglypha sp 1

Netzelia sp (Ogden, 1979)

Pseudodifflugia gracilis (Schlumberger, 1845)

Pyxidicula SP

Total abundance

Richness

\begin{tabular}{|c|c|c|c|c|c|}
\hline 1 & 1 & 6 & 1 & 4 & 7 \\
\hline 85 & 359 & 120 & 32 & 112 & 78 \\
\hline 2 & 0 & 0 & 0 & 0 & 0 \\
\hline 5 & 12 & 40 & 0 & 0 & 17 \\
\hline 0 & 216 & 133 & 0 & 184 & 136 \\
\hline 0 & 1 & 1 & 0 & 0 & 0 \\
\hline 1 & 0 & 1 & 0 & 0 & 0 \\
\hline 0 & 1 & 0 & 0 & 0 & 0 \\
\hline 0 & 1 & 0 & 0 & 0 & 0 \\
\hline 0 & 0 & 1 & 0 & 0 & 0 \\
\hline 0 & 1 & 0 & 0 & 0 & 0 \\
\hline 1 & 3 & 3 & 0 & 0 & 0 \\
\hline 0 & 0 & 1 & 0 & 0 & 0 \\
\hline 0 & 2 & 1 & 0 & 0 & 0 \\
\hline 0 & 3 & 1 & 0 & 0 & 0 \\
\hline 1 & 11 & 0 & 0 & 0 & 0 \\
\hline 0 & 1 & 0 & 0 & 0 & 0 \\
\hline 0 & 2 & 2 & 0 & 0 & 0 \\
\hline 1 & 0 & 0 & 0 & 0 & 0 \\
\hline 1 & 1 & 5 & 0 & 0 & 0 \\
\hline 0 & 23 & 30 & 0 & 0 & 0 \\
\hline 0 & 0 & 1 & 0 & 0 & 0 \\
\hline 0 & 0 & 1 & 0 & 0 & 0 \\
\hline 0 & 0 & 1 & 0 & 0 & 0 \\
\hline 0 & 1 & 0 & 0 & 0 & 0 \\
\hline 0 & 0 & 1 & 0 & 0 & 0 \\
\hline 0 & 1 & 0 & 0 & 0 & 0 \\
\hline 0 & 3 & 7 & 1 & 6 & 2 \\
\hline 1 & 3 & 3 & 0 & 0 & 0 \\
\hline 0 & 2 & 0 & 0 & 0 & 0 \\
\hline 0 & 0 & 2 & 0 & 0 & 0 \\
\hline 0 & 0 & 1 & 0 & 0 & 0 \\
\hline 0 & 0 & 1 & 0 & 0 & 0 \\
\hline 0 & 8 & 11 & 0 & 5 & 4 \\
\hline 0 & 0 & 0 & 1 & 0 & 0 \\
\hline 0 & 2 & 0 & 1 & 0 & 0 \\
\hline 0 & 0 & 1 & 0 & 1 & 0 \\
\hline 0 & 2 & 2 & 1 & 0 & 0 \\
\hline 0 & 1 & 0 & 0 & 0 & 0 \\
\hline 3 & 0 & 0 & 0 & 0 & 0 \\
\hline 163 & 1008 & 964 & 77 & 581 & 450 \\
\hline 9 & 13 & 14 & 5 & 7 & 7 \\
\hline
\end{tabular}

First two axis of CCA ordination were found to be significant $(\mathrm{p}<0.01)$ and had eigenvalues of 0.19 and 0.13 , respectively. First ordination axis explains $21.7 \%$ of canonical variance and synthesizes principally seasonal effects in species abundance (Fig. 2).

This axis is positively related with $\mathrm{pH}, \mathrm{DO}, \mathrm{TC}, \mathrm{FC}$ and Alkalinity, variables with higher values during the dry season characterized by low river discharge. High abundances of Arcella discoides, Difflugia pristis, Difflugia gramen e Difflugia mica were related to these conditions. Difflugia gramen and Difflugia mica are hereby located on the extreme right side of ordination diagram. As further exposed in the discussion, preferences of this seems to be linked however to altering hydrodynamic conditions and the difficulties of Difflugiidae to adhere to substrate than to a reduced tolerance to 
physical and chemical pollution. Arcella vulgaris are related to higher values of alkalinity and present little tolerance to higher taxes of organic pollution during the wet season, presented by its opposite location to the COD and BOD vectors. First axis is negatively related to COD, BOD, Turbidity, Color, Total Solids, TP and TNK discriminating the wet season, when values of these variables rise. The species which mainly occur under these conditions were Centropixys ecornis, Arcella hemisphaerica, Cochliopodium vestitum e Centropixys aculeata.

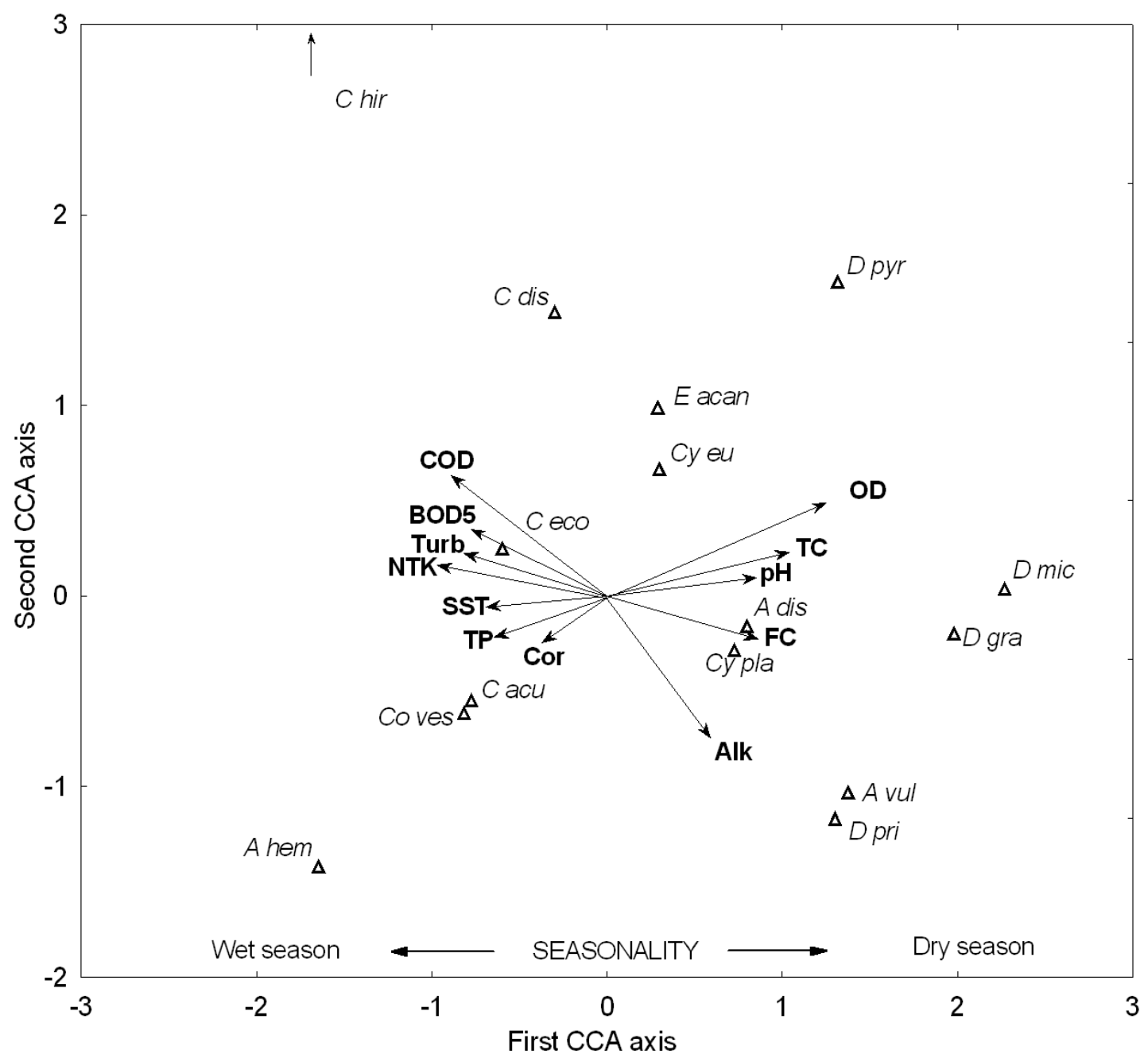

A dis: Arcella discoides; A hem: Arcella hemisphaerica;

C acu: Centropixys aculeata; $C$ dis: Centropixys discoides; $C$ eco: Centropixys ecornis; $C$ hir:

Centropixys hirsuta

Co ves: Cochliopodium vestitum

Cy eu: Cycopyxis euristoma

Cy pla: Cyclopyxis plana microstoma

D gra: Difflugia gramen; D mic: Difflugia mica; D pri: Difflugia pristis; D pyr: Difflugia pyriformis

E acan: Euglypha acanthophora

Figure 2. First two factorial axis of CCA. In the ordination, only species with a relative frequency above $20 \%$ were considered. 
The two last species, in accordance to their location along the second CCA axis, seem to have preferences to higher TP concentrations. Centropixys ecornis seems to benefit by higher concentrations of organic material, evidenced by its location near the ordination vectors of COD, BOD and Turbidity. Alkalinity has the highest (negative) contribution to the second ordination axis, which explains $15.1 \%$ of CA variance. Arcella hemisphaerica is ordered on the lower left side of the biplot, indicating a relation to higher Alkalinity, but coupled with higher nutrient levels found during the wet season. Species positively related to this axis are Centropixys hirsuta, Centropixys discoides, Cycopyxis euristoma, Difflugia pyriformis and Euglypha acanthophora, when Arcella hemisphaerica is ordered at the opposite site of the biplot.

\section{Discussion}

This study presents a characterization of periphyton testaceae assemblages in a tropical freshwater ecosystem in the Central-Western Brazilian Cerrado region and its relationships to physical-chemical and biological measurements of water quality. More specifically, exploratory analysis and CCA direct gradient analysis were applied to evaluate species distribution along a quality gradient of urban river reaches, and to compare frequencies and richness during the dry and wet seasons. Results of applied empirical methods to relate assemblages with environmental factors must not be misinterpreted that they are necessarily explaining causal relationships between structure and composition and measured external variables. In our case, water quality of the studied river reach is heavily influenced by hydrodynamics, which determine components of the periphython testatacea assemblages. This is further detailed and exemplified in following.

Total richness of periphyton tecamebiana fauna as found in this study (53 species) is similar to the 49 species reported by Hardoim (1997) on natural substrates in the Bento Gomes stream, an affluent of the northern Pantanal, about $100 \mathrm{~km}$ south of our study area. About 2/3 of sampled species were found to be rare. Rare species are in their majority are pertaining to Difflugidae family, similar as the results obtained by Silva Neto (2001) in planctonic samples of urban reaches of the Cuiabá river. Cochliopodium vestitum, Cyclopyxis plana microstoma and Centropyxis aculeata were found to be the three most abundant species, each of them dominant during one sampling date. In accordance, Missawa (2000) stated Centropyxis aculeata to be one of the three species most abundant species in planctonic communities in the main urban reaches of the Cuiabá river. Silva Neto (2001) found the family Centropyxidae to be the most abundant in an urban Cuiabá river reach, about $100 \mathrm{~km}$ river ahead of Cuiabá city. Cochiopodium vestitum has not been reported in none of the cited regional studies and Cyclopyxis plana microstoma was generally found to be rare in plankton assemblages. Abundant in present research, both species, which are characterized by flattened shell form, seem to be morphologically well adapted to the periphyton.

Generally, environmental preferences of studied periphyton organisms could be detected with more clarity for samplings from the dry, low water season. We suppose that this is due to a higher stability in environmental conditions, contrary to those of the wet season, when hydrodynamic and physical-chemical conditions oscillate frequently, caused by rainfalls and varying loads of aloctone material. Installation of assemblages seems to be more difficult under these conditions and total abundance and richness decrease. During the wet season some glass slides were partially covered by 
sedimentation, too, a shortcoming of applied periphyton sampling procedure on artificial substrates.

Our investigations did not conduct systematic work to evaluate, if it were limnological or hydrodynamic gradients, which cause variations in assemblages at artificial substrates between the dry and wet season. Nevertheless, richness of assemblages is impoverished during the wet season, when almost all Difflugiidae disappear. Studies such as those of Bobrov and Mazei (2004) and Wanner and Meisterfeld (1994) conclude that morphologic aspects of testate amebas influence abundance in different habitats. Difflugiidae are known to be widely unable to adhere to artificial surfaces, which may explain their absence at sampling campaigns from the wet season, with higher discharge and flow velocities. As examples, Difflugia gramen and Difflugia lucida have rounded shells, impeding permanence in the periphyton of reaches with higher runoff velocities. Similar, Arcella vulgaris which has previously been observed in the periphyton as well as in plankton assemblages of the study area (Hardoim and Heckman, 1996) was abundant during the dry season and disappeared during the wet season. Velho et al. $(1999,2004)$ pointed out that this species is more abundant in lentic than in lotic systems. The higher abundance during the period with lower runoff velocities suggests the that hemispheric form of shell may difficult permanence of Arcella vulgaris in the periphyton during the wet season.

There is however clear evidence in our data and previous studies that differences in assemblage structure and species abundance are not independent of water quality or exclusively determined by hydrodynamics of habitats. The genus Difflugia was found to be better adapted to environmental conditions during the dry season not only in the periphyton but as well in planktonic communities river ahead of Cuiabá city (Silva Neto, 2001). In our study, Difflugia mica was always absent at Rc5, but frequent at the impacted Rc8 and with 23 and 30 counts, respectively during the dry and wet season. Moreover Centropyxis aculeate, Centropyxis ecornis, Centropyxis discoides, Cochlipodium vestitum and Cyclopyxis eurystoma were always several times more frequent at the impacted stations (Rc8, Rc12) than at Rc5, river ahead the urban area, this independent of the climatic period of the year. Contrary, Centropixys aculeata, when reported in the Pantanal was abundant under different water conditions (Hardoim, 1997).

Euglypha acanthophora only occurred at Rc8 and Rc12, a species already reported for plankton communities of the Cuiabá River (Missawa, 2000; Silva Neto, 2001) and in periphyton of the Pantanal of Poconé (Hardoim, 1997). In this last study, species presence was observed in slightly acid waters with low or intermediate saturation of DO, conditions common as well at both impacted stations of our study.

The preference for elevated nutrients loads and organic pollution is seen even more clearly for Cyclopyxis plana microstoma, which was never observed at Rc5, but had counts higher than 100 during the dry and the wet season under deteriorated water quality conditions. The species revealed therefore potential to be used as indicator for mesotrophic environments.

Higher abundances of Arcella hemisphaerica were only observed during the wet season, or at the impacted Rc8 station during the dry season. Arcella hemisphaerica has been described as common in mesotrophic environments, tolerant to organic pollution (Opravilová and Zelinka, 1978). Hardoim (1997) observed higher abundance of this species at the beginning and during the rainy season, at an impacted sampling station of Bento Gomes river in the border region between the Cuiabá depression and the northern 
Pantanal floodplain. Differing to our results, where Arcella discoides seem to prefer enriched environments the species has been described in the Pantanal region as common, tolerant to different ecological water conditions, and abundant during low and high water conditions (Hardoim, 1997). Similar findings were obtained by studies from temperate climates (Sládecekova, 1962; Opravilová and Zelinka, 1978), where Arcella discoides is tolerant to broad variations of saprobity.

\section{Conclusions}

In the urban reach of the Cuiabá river, Testacean communities alter as a function of hydrodynamics and changing water quality between dry and wet season and between sampling stations. Richness and abundance is higher during the dry season and in the downstream sampling points, both characterized by lower oxygenation levels and higher nutrient concentrations.

Difflugia species are almost absent during the wet seasons. As there is evidence that this occurs mainly due to differences in river discharge, this genus has little potential as water quality indicator. Contrary, species such as Cyclopyxis plana microstoma and Euglypha acanthophora only occur at impacted sampling stations at both seasons, indicating a potential to indicate deteriorated water quality conditions.

\section{REFERENCES}

[1] Anderson, M.J., Ter Braak, C.J.F. (2003): Permutation tests for multi-factorial analysis of variance. - Journal of Statistical Computation and Simulation 73: 85-113.

[2] Barinova, S.S., Tavassi, M., Nevo, E. (2006): Algal indicator system of environmental variables in the Hadera River basin, central Israel. - Plant Biosystems 140: 65-79.

[3] Bobrov A.A., Mazei, Y. (2004): Morphological variability of testate amoebae (Rhizopoda: Testacealobosea: Testaceafilosea) in natural populations. - Acta Protozoologica 43: 133-146.

[4] Brown, S.D., Austin A.P.A. (1971): Method of Collecting Periphyton in Lentic Habitats with Procedures for Subsequent Sample Preparation and Quantitative Assessment. Internationale Revue der gesamten Hydrobiologie und Hydrographie 56: 557-580.

[5] Cairns Jr., J.D., Kuhn, L., Plafkin, J.L. (1979): Protozoan colonization of artificial substrates. - In: Weitzel, R.L. (ed.). Methods and measurements of periphyton communities: A review. American Society for Testing and Materials, Michigan.

[6] Carr, G.M., Morin, A., Chambers, P.A. (2005): Bacteria and algae in stream periphyton along a nutrient gradient. - Freshwater Biology 50: 1337-1350.

[7] Castenholz, R.W. (1961): An Experimental Study of the Vertical Distribution of Littoral Marine Diatoms. - Limnology and Oceanography 8: 450-462.

[8] Cooke, W.B. (1956): Colonization of artificial bare areas by microrganisms. - Botanical Review 22: 613-638.

[9] Cunha, A.M. (1916): Contribuição para o conhecimento da fauna de protozoários no Brasil. Memórias do Instituto Oswaldo Cruz 8: 66-73.

[10] Escobar, J., Brenner, M., Whitmore, T.J., Kenny, W.F., Curtis, J.H. (2008): Ecology of testate amoebae (Thecamoebians) in subtropical Florida lakes. - Journal of Paleolimnology 40: 715-731.

[11] Gaiser, E.E., Childers, D.L., Jones, R.D., Richards, J.H., Scinto L.J., Trexler, J.C. (2006): Periphyton responses to eutrophication in the Florida Everglades: Cross-system patterns of structural and compositional change. - Limnology and Oceanography 51: 617-630. 
[12] Godinho-Orlandi, M.J.L., Barbieri, S.M. (1983): Observação de microorganismos perifíticos (bactérias, protozoários e algas) na região marginal de um ecossistema aquático. - In: III Seminário Regional de Ecologia, São Carlos, pp. 135-155.

[13] Green, J. (1975): Freshwater Ecology in the Mato Grosso, Central Brazil. IV. Associations of Testate Rhizopoda. - Journal of Natural History 9: 545-560, 1975.

[14] Guisan, A., Weiss S.B., Weiss, A.D. (1999): GLM versus CCA spatial modeling of plant species distribution. - Plant Ecology 143: 107-122.

[15] Hardoim, E. L. (1997): Taxonomia e ecologia de Testacea (Protista, Rhizopoda) do Pantanal do Poconé - Rio Bento Gomes e Vazante Birici, Mato Grosso, Brasil. - Doctoral Dissertation, Universidade Federal de São Carlos, São Carlos.

[16] Hardoim, E.L., Heckman, C.W. (1996): The seasonal succession of biotic communities in Wetlands of the Tropical wet-and-dry climatic zone: IV The free-living Sarcodines and Ciliates of the Pantanal of Mato Grosso, Brazil. - Internationale Revue der gesamten Hydrobiologie und Hydrographie 81: 367-384.

[17] Jax, K. (1996): The influence of substratum age on patterns of protozoan assemblages in freshwater Aufwuchs - a case study. - Hydrobiologia 317: 201-208.

[18] Kralik, U. (1957/58): Untersuchungen über den Bewuchs von peritrichen Ciliaten in einigen Fliessgewassern bei Leipzig. - Wissenschaftliche Zeitschrift der Karl-MarxUniversitaet Leipzig 7: 309-328.

[19] Kumar, A., Patterson, R.T. (2000): Arcellaceans (thecamoebians): new tools for monitoring long - and short-term changes in lake bottom acidity. - Environmental Geology 39: 689-697.

[20] Lahr, D.J.G., Lopes, S.G.B.C. (2006): Morphology, Biometry, Ecology and Biogeography of Five Species of Difflugia Leclerc, 1815 (Arcellinida: Difflugiidae), from Tiete River, Brazil. - Acta Protozoologica 45: 77-90.

[21] Lampert, W., Sommer, U. (1997): Limnoecology: The ecology of lakes and streams. Oxford University Press, New York.

[22] Lansac-Tôha, F.A., Alves, G.M., Velho, L.F.M., Robertson, B.A., Joko, C.Y. (2008): Composition and occurrence of testate amoebae in the Curuá-Una Reservoir (State of Pará, Brazil). - Acta Limnologica Brasiliensia 20: 177-195.

[23] Lansac-Tôha, F.A., Zimmermann-Callegari, M.C., Alves G.M., Velho, L.F.M, Fulone, L.J. (2007): Species richness and geographic distribution of testate amoebae (Rhizopoda) in Brazilian freshwater environments. - Acta Scientiarum 29: 185-195.

[24] Lansac-Tôha, F.A., Velho, L.F.M, Zimmermann-Callegari, M.C., Bonecker, C.C., Takahashi, E.M. (2001): On the occurrence of testate amoebae (Protozoa, Amoebozoa, Rhizopoda) in Brazilian inland waters. III. Family Difflugiidae: Genus Difflugia. - Acta Scientiarum 23: 305-321.

[25] Lansac-Tôha, F.A., Velho, L.F.M, Bonecker, C.C., Aoyagui, A.S.M. (2000): Horizontal distribution patterns of testate amoebae (Protozoa, Rhizopoda) in plankton samples of Corumbá Reservoir area, state of Goiás, Brazil. - Acta Scientiarum 22: 347-353.

[26] Legendre, P., Gallagher, E.D. (2001): Ecologically meaningful transformations for ordination of species data. - Oecologia 129: 271-280.

[27] Makarenkov, V., Legendre, P. (2002): Nonlinear redundancy analysis and canonical correspondence analysis based on polynomial regression. - Ecology 83: 1146-1161.

[28] Missawa, N. (2000): Influência das alterações físicas e químicas provocadas por poluentes orgãnicos na estrutura de comunidades de Testacea (Protozoa: Rhizopoda) no Rio Cuiabá, Cuiabá - Mato Grosso. Master Thesis, Universidade Federal do Mato Grosso, Cuiabá.

[29] Ogden, C.G., Hedley, R.H. (1980): An Atlas of Freshwater Testate Amoebae. An Atlas of Freshwater Testate Amoebae. Oxford University Press, Oxford.

[30] Opravilova, V., Zelinka, M. (1978): The importance of Testacea for the evaluation of stream pollution. - Folia Facultatis Scientaiarum Naturalium Universitatis Purknianae Brunensis 19: 53-60. 
[31] Opravilova, V. (1986): Testacea (Protozoa: Rhizopoda) in the Epilithion of the Lotic Stretch of Running Waters of Different Degrees of Saprobity (Czechoslovakia). - Acta hydrochimica et Hydrobiologica 14: 667-672.

[32] Patterson, R.T., Kumar, A. (2002): A review of current testate rhizopod (Thecamoebian) research in Canada. - Palaeogeography, Palaeoclimatology, Palaeoecology 180: 225-251.

[33] Schwarzbold, A. (1990): Métodos ecológicos aplicados ao estudo do perifiton. Acta Limnologica. - Brasiliensia 3: 545-592.

[34] Sládecková, A. (1962): Limnological investigation methods for periphyton (“Aufwuchs") community. - Botanical Review 28: 286-350.

[35] Sládecková, A., Sládecek, V. (1993): Bioindication within the Aquatic Environment. Acta Universitatis Carolinae Environmentalica 7: 3-69.

[36] Silva Neto, E.V. (2001): Índices ecológicos de comunidades de Testacea (Protozoa: Rhizopoda) no rio Cuiabá, perímetro urbano de Rosário Oeste, Mato Grosso. Master thesis, Universidade Federal do Mato Grosso, Cuiabá.

[37] Strüder-Kypke, M.C. (1999): Periphyton and sphagnicolous protists of dystrophic bog lakes (Brandenburg, Germany) I. Annual cycles, distribution and comparison to other lakes. - Limnologica - Ecology and Management of Inland Waters 29: 393-406.

[38] Ter Braak, C.J.F., Prentice, I.C. (1988): A theory of gradient analysis. - Advanced Ecological Research 18: 271-313.

[39] Velho, L.F.M., Lansac-Tôha, F.A., Bini, L.M. (1999): Spatial and temporal variation in densities of testate amoebae in the plankton of the Upper Paraná river floodplain, Brazil. Hydrobiologia, 411: 103-113.

[40] Velho, L.F.M., Alves, G.M., Lansac-Tôha, F.A.L., Bonecker, C.C., Pereira, G.D. (2004): Testate amoebae abundance in plankton samples from Paraná State reservoirs. - Acta Scientiarum 26: 415-419.

[41] Vis, C., Hudon, C., Cattaneo, A., Pinel-Alloul, B. (1998): Periphyton as an indicator of water quality in the St Lawrence River (Québec, Canada). - Environmental Pollution 101: 13-24.

[42] Walker, I. (1982): The thecamoebae (Protozoa, Rhizopoda) of small Amazonian forest streams and their possible use as indicator organisms for water quality. - Acta Amazonica 12: 79-105.

[43] Wanner, M., Meisterfeld, R. (1994): Effects of some environmental factors on the shell morphology of testate amebas (Rhizopoda, Protozoa). - European Journal of Protistology, 30: 191-195.

[44] Ward, J. V. (1989): The four dimensional nature of lotic ecossystems. - Journal of the North American Bentological Society 8: 2-8.

[45] Zeilhofer, P., Lima, E.B.N.R., Lima, G.A.R. (2010): Land use effects on water quality in the urban agglomeration of Cuiaba and Varzea Grande, Mato Grosso State, central Brazil. - Urban Water Journal 7: 173-186. 